\title{
FACTORS INFLUENCING CONSUMERS IN USING SHOPEE FOR ONLINE PURCHASE INTENTION IN EAST COAST MALAYSIA
}

\author{
KIEW CHEE CHING ${ }^{1}$, ZUHA ROSUFILA ABU HASAN ${ }^{1 *}$ AND NADIA ABU HASAN ${ }^{2}$ \\ ${ }^{1}$ Faculty of Business, Economics and Social Development, Universiti Malaysia Terengganu, 21030 Kuala Nerus, \\ Terengganu Darul Iman, Malaysia \\ ${ }^{2}$ Faculty of Law, Multimedia University, 75450 Melaka, Malaysia
}

"Corresponding author: zuha@umt.edu.my

http://doi.org/10.46754/umtjur.2021.01.006

\begin{abstract}
Shopee online has become increasingly popular among consumers for purchasing purposes as compared to brick-and-mortar retail due to the benefits and enjoyment that come with it. However, Shopee has facing intense competitive challenges with other competitors in Malaysia. In addition, it is also difficult for Shopee to compete with major leader of online shopping portal although this platform offers the same function and usage as its contender. Hence, it is important to understand consumer perceptions on the benefit and intention of using Shopee. This study examines consumer perceived usefulness, perceived ease of use, perceived price, perceived convenience and perceived trust adapted from the Technology Acceptance Model (TAM). 208 respondents who have experience online purchasing in East Cost of Malaysia were invited to participate in this study using online survey. Data were analyzed using descriptive, correlation and multiple regression analyses. The findings show that perceived convenience and perceived trust have strong influence towards consumer intention to use Shopee as platform to do online purchase. It is suggested that this study will help practitioners to understand consumer online shopping perception and intention in order to induce visitation and usage of Shopee.
\end{abstract}

Keywords: Perceived benefit, Technology Acceptance Model, Intention, Shopee.

\section{Introduction}

The Information Technology and Communication (ICT) has grown rapidly in Malaysia (Alias, 2018). In 2018, the number of internet users in Malaysia is 21.93 million and will continue to grow in the future thus creating a window of opportunity for online shopping. Malaysian consumer often uses online shopping platform such as Shopee to purchase item. Shopee has been launched in Malaysia in 2015 with 501 to 1000 employees (Nee, 2017).

Shopee is the second highest of the top 50 e-commerce players in Malaysia based on the average quarterly traffic, social media followers, mobile application rankings and the number of employees (The Sun Daily, 2018). There are many services provided by Shopee such as logistic and customer support, secure payment methods, shopping and chatting with sellers. This online shopping platform also enables online consumer to shop anytime and anywhere with the wide variety of mall sellers and trusted marketplace seller who offer the best deals and vast savings (Shopee, 2019). According to iPrice (2018), the monthly visit rate was $12,330,200$ users, thus ranking second behind Lazada and outperformed other competitors such as 11th Street, Lelong, Zalora, eBay and others.

However, Shopee has encountered difficulty in competing with Lazada from all aspects in terms of monthly visit rate or the type of businesses model used to achieve an operational excellence (Lim, 2017). In addition, according to Shopee Malaysia 
Complaints Board, this online platform also must deal with common problems such as refund problem, product defect and poor customer service (ComplaintsBoard.com, 2019).

Thus, it is important to study consumer perception of Shopee to understand what makes them choose these online shopping platforms. In the academic perspective, there have been intensive studies on online shopping attitudes and behaviour in recent years (Li and Zhang, 2002). However, the past researchers are not fully examined on the benefits consumer will receive if they choose Shopee as a platform to purchase.
Hence, the aim of the present study is to examine the factors that influence consumer intention to do online purchase using Shopee among consumers resided in East Coast of Malaysia. Apart from that, the study wished to study the degree of relationship between perceived usefulness, perceived ease of use, perceived price, perceived convenience, perceived trust, and intention to use Shopee as an online shopping platform. This study adapted the Technology Acceptance Model (TAM). Figure 1 shows research framework for the present study.

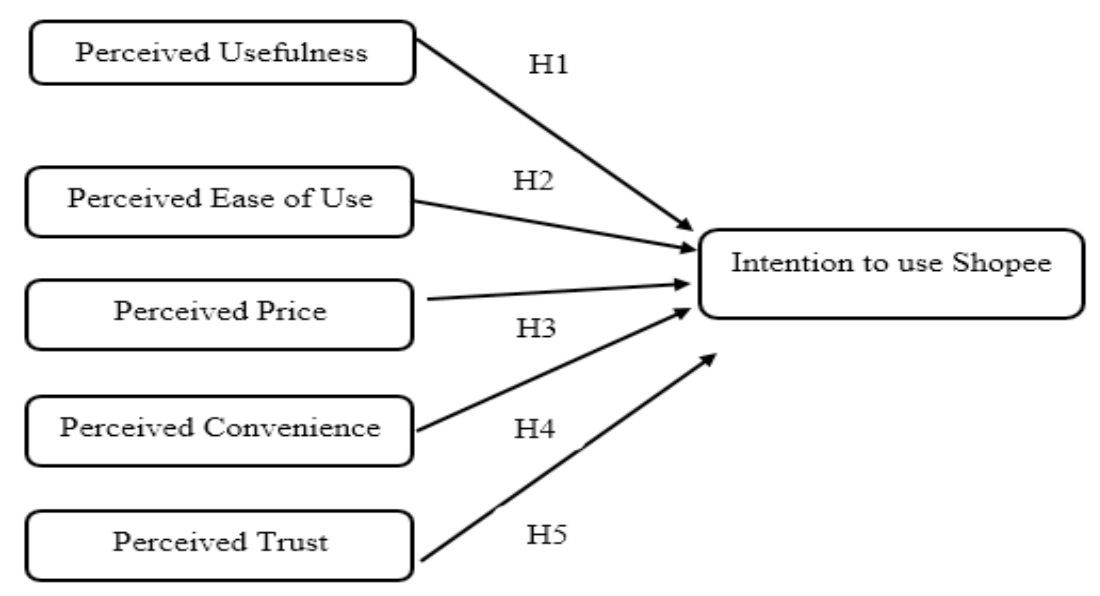

Figure 1: Research framework

\section{Perceived Benefit of Online Shopping}

Consumer behavior is the study of how individuals, groups and organizations make decisions regarding selecting, purchasing, using, evaluating, and disposing the product or service that can satisfy their need and wants and become a loyal consumer (Rafsandjani, 2018). It is a process whereby consumer make a choice, decide to purchase, choose to use, or dispose the product, service, so that can fulfil their need and want can be fulfilled (Kim, 2004). Now, consumer have the choice to shop via online or offline channel provided these channels can provide satisfaction or benefit for them. However, online shopping is preferable due to easier process and prices offered are lowered than offline shopping (Gupta, 2015). It has supported by Sarkar (2011) that an online shopper with higher utilitarian shopping motive is likely to perceive greater benefits in online shopping.

Perceived benefit is an individual's belief about the specific positive outcomes related to a specific behaviour. The perceived benefit of consumer buying 
structure is frequently applied to normal shopping behaviour while it is also a consumer' perception of the benefit that generate satisfaction after participating in a specific shopping action (Tingchi Liu, et al., 2013). Perceived benefits will influence consumer's online shopping attitude, intention and behaviour (Ahmed, et al., 2017). The utilitarian benefits such as perceived ease of use, perceived usefulness and price are the sum of the perceived benefits in online shopping (Sarkar, 2011).

\section{Technology Acceptance Model (TAM)}

Technology Acceptance Model (TAM) is a theoretical model that can be used to forecast consumers' online purchase intention through technology as well as study the consumer acceptance on e-commerce circumstance at the same time. TAM consists of five variables which are perceived ease of use, perceived usefulness, actual usage, attitude towards using and behavioural intention to use. The perceived usefulness and perceived ease of use in the TAM model are related to the computer use behaviours and are most significant determinants of the actual system use (Surendran, 2012).

Perceived usefulness is the degree to which a person believes that using Internet system will enhance his/her purchasing performance (Liat \& Wuan, 2014). The perceived usefulness is the main element that will strongly influence consumer purchase online compared with perceived ease of use. Perceived ease of use refers to the degree to which the prospective user expects the target system to be free of effort (Surendran, 2012). There are two vital aspects that can enhance the perceived ease of use and increase the consumer's online purchase intention which are easy and simple to checkout process and the effective product searching tools (Liat \& Wuan, 2014). Attitude towards using is an action-driven by an Expectancy-Value
Model of beliefs, weighted by evaluations of the consequences and the consumers' desirability of them using the system being studied. A favourable attitude can generate good results in using Web shopping system usage however unfavourable attitudes will influence the result in under-utilization of the system, or abandonment using Web shopping (Fenech, 2000). Consumer behavioural intention will lead to the actual usage of using online shopping (Lin, 2007). The present study examines perceived usefulness and perceived ease of use which influence consumer online purchase intention using Shopee among consumer in East Coast of Malaysia.

\section{Perceived Price, Convenience and Trust}

Price is the amount of money that was required in paying for something such as product or service and as sum of the monetary cost to buy product or service (Tan, et al., 2011). The consumer's reactions to the price were influenced by information and details about product or transaction cost and accessibility through mass media (Rana, et al., 2015). It can be said that price is the major motivation that influence consumer to perform online purchase. It has been supported by Liew (2015) that pricing is a useful way to motivate price sensitive consumers to gain the larger value for their money or to buy a product at the lower price.

Convenience is estimated by a structure within the three elements which are the time consume, location to shop and purchase process. It can effectively motivate consumer to purchase online. It can be said that convenience is a major motivation or factor to motivate consumer to choose online platform rather than physical shop (Delafrooz, et al., 2009). It has been supported by Chiang and Dholakia (2003) that consumer intention towards online shopping is greater when they realize that the offline shopping is inconvenient for them. 
Perceived trust is an important aspect in online shopping due to the nature of online process which is less face-to-face interaction. According to Tingchi Liu et al. (2013), trust is extremely vital in online shopping and it is different with traditional shopping because online shopping has the special aspect such as insecurity, anonymity and weak of control. Consumer often depend on trusted online shopping platform to purchase online products or services (Aineah, 2016). Thus, trust is an important component in order to establish long term relationship between retailer, consumer, and a company's market share by Shopee (Pardede, et al., 2018).

\section{Online Purchase Intention}

Purchase intention is referring to the percentage of consumer intend to buy the products or services (Sam, et al., 2009). The online purchase intention is a situation when consumer wants to purchase an item or service through online platform (Liat \& Wuan, 2014). Several research has shown that there are strong relationship between attitude and preference toward a product that can measure the purchase intention of consumers' future behaviour based on their attitude (Kim \& Ko, 2012). For example, the motivation that inspire consumer to choose online shopping as it can save time, more convenience and easier to use. It has been supported by Ahmed et al. (2017) that online shopping is convenience because it can shorten the time in the process of purchase.

\section{Methods}

Non-probability sampling in the form of quota sampling technique was chosen for this research. Survey data were gathered from the three main cities in the East Coast Malaysia which are Kuala Terengganu, Kota Bharu and Kuantan. Survey data were collected among 208 respondents via online survey namely 85 respondents $(40.9 \%)$ in Kuala Terengganu, 64 respondents $(30.8 \%)$ in Kota Bharu and 59 respondents (28.3\%) in Kuantan. Pre-test was conducted to 30 respondents. They were asked verbally to comment on the layout of the survey, completion time, measurement scales and wording, instruction as well as any misinterpretation of questions. The pre-test findings show that most of the respondents had no problem with the instructions and misinterpretation of the questions.

\section{Instrument}

Online survey via Google forms was selected as the instrument for this study due to easy data collection and handling. The questionnaire is divided into seven sections which are demographic characteristics, perceived useful, perceived ease of use, perceived price, perceived convenience and perceived trust and consumer purchase intention. The questionnaire consists of 5-point Likert scale in which respondent need to specify their degree of agreement or disagreement on a symmetric agreedisagree scale for each question. Summary of the questionnaires are shown in Table 1.

Table 1: Summary of the questionnaires

\begin{tabular}{cccc}
\hline Sections & Items & No. of Questions & Measurement Scale \\
\hline A & Perceived Usefulness & 7 & Likert Scale \\
B & Perceived Ease of Use & 7 & Likert Scale \\
C & Perceived Price & 6 & Likert Scale \\
D & Perceived Convenience & 7 & Likert Scale \\
E & Perceived Trust & 7 & Likert Scale \\
F & Intention to Use & 7 & Likert Scale \\
G & Demographic Data & 12 & Nominal Scale \\
\hline
\end{tabular}




\section{Results}

The findings were organized into 5 parts: characteristics of the respondent, reliability of the scales, hypotheses testing, relationship between variables, and degree of relationship between variables.

\section{Part One: Characteristics of the Respondent}

The respondent's profile and other relevant background information were analysed using descriptive analysis. Descriptive analysis can be defined as summarizing the basic finding for the sample in the research
(Burns, \& Bush, 2014). Table 2 shown the summary of the findings on demographic characteristics. The profile indicates that $66.8 \%$ of the respondents were female while the remainder were male. Majority of the respondent's age was between 18 to 25 years old, bachelor degree, single status, and live in urban areas. In terms of online shopping behavior, $51 \%$ of the respondents only purchase once per month via online. $56.7 \%$ of the respondent's online spending pattern was below RM100 per month. They preferred to buy online clothes and accessories as well as shoes and bags.

Table 2: Summary of demographic characteristics

\begin{tabular}{|c|c|c|}
\hline Characteristics & Frequency & Percentage \\
\hline \multicolumn{3}{|l|}{ AGE } \\
\hline $18-25$ & 141 & 67.8 \\
\hline $26-30$ & 22 & 10.6 \\
\hline $31-35$ & 22 & 10.6 \\
\hline $36-40$ & 11 & 5.3 \\
\hline Above 40 & 12 & 5.8 \\
\hline \multicolumn{3}{|l|}{ GENDER } \\
\hline Male & 69 & 33.2 \\
\hline Female & 139 & 66.8 \\
\hline \multicolumn{3}{|l|}{ ETHNIC GROUP } \\
\hline Malay & 76 & 36.5 \\
\hline Chinese & 112 & 53.8 \\
\hline Indian & 19 & 9.2 \\
\hline Others & 1 & 0.5 \\
\hline \multicolumn{3}{|c|}{$\begin{array}{l}\text { ANNUALLY INCOME (INCLUDE STUDENTS LOAN/ } \\
\text { ALLOWANCES) }\end{array}$} \\
\hline Below RM 10000 & 151 & 72.6 \\
\hline RM 10 001-RM 50000 & 43 & 20.7 \\
\hline Above RM 50001 & 14 & 6.7 \\
\hline \multicolumn{3}{|l|}{ CURRENT OCCUPATIONAL } \\
\hline Student & 136 & 65.4 \\
\hline Government Sector & 21 & 10.1 \\
\hline Private Sector & 47 & 22.6 \\
\hline Unemployed & 4 & 1.9 \\
\hline
\end{tabular}




\begin{tabular}{|c|c|c|}
\hline \multicolumn{3}{|l|}{ HIGHEST EDUCATION } \\
\hline High School or Equivalent & 30 & 14.4 \\
\hline Diploma & 25 & 12.0 \\
\hline Bachelor's degree & 149 & 71.6 \\
\hline Master & 2 & 1.0 \\
\hline Ph.D. & 1 & 0.5 \\
\hline Others & 1 & 0.5 \\
\hline \multicolumn{3}{|l|}{ CURRENT RESIDENT } \\
\hline Terengganu & 85 & 40.9 \\
\hline Kelantan & 64 & 30.8 \\
\hline Pahang & 59 & 28.4 \\
\hline \multicolumn{3}{|l|}{ AREA OF RESIDENT } \\
\hline Urban & 141 & 67.8 \\
\hline Sub- urban & 67 & 32.2 \\
\hline \multicolumn{3}{|l|}{ MARITAL STATUS } \\
\hline Single & 175 & 84.1 \\
\hline Married & 33 & 15.9 \\
\hline \multicolumn{3}{|c|}{$\begin{array}{l}\text { HOW MANY TIMES PURCHASE THROUGH ONLINE } \\
\text { PER MONTH? }\end{array}$} \\
\hline Once & 106 & 51.0 \\
\hline Twice & 55 & 26.4 \\
\hline Three Times & 27 & 13.0 \\
\hline Above Three Times & 20 & 9.6 \\
\hline \multicolumn{3}{|c|}{$\begin{array}{l}\text { HOW MUCH SPEND ON ONLINE SHOPPING PER } \\
\text { MONTH? }\end{array}$} \\
\hline Below RM 100 & 118 & 56.7 \\
\hline RM 101- RM 500 & 58 & 27.9 \\
\hline RM 501- RM 1000 & 26 & 12.5 \\
\hline Above RM 1001 & 6 & 2.9 \\
\hline \multicolumn{3}{|c|}{ TYPE OF PRODUCT USUALLY SHOP ONLINE } \\
\hline Home and Living & 42 & 9.3 \\
\hline Clothes and Accessories & 102 & 22.6 \\
\hline Shoes and Bags & 89 & 19.7 \\
\hline Health and Beauty & 55 & 12.2 \\
\hline Game, Books and Hobbies & 29 & 6.4 \\
\hline Computer and Accessories & 51 & 11.3 \\
\hline Mobile and Tools & 39 & 8.6 \\
\hline Toys, Kids and Babies & 4 & 0.9 \\
\hline Sport and Outdoor & 34 & 7.5 \\
\hline Others & 7 & 1.5 \\
\hline
\end{tabular}

Part Two: Reliability of the Scales 
Reliability is the extent to which an instrument is error free and thus, consistent, and stable across time and across the various items in the scale (Rafsandjani, 2018). Table 3 shows the results for reliability of the scales. The cut off criteria can exceed 0.50 which follows the rule of thumb (Abu Hasan, 2011). The Cronbach's alpha coefficients of the perceived ease of use, perceived price, perceived convenience, perceived trust, and intention to use variables were reported below 0.7 and the perceived usefulness variable reported above 0.7 . This means that the scales used in the present study are reliable.

Table 3: Reliability analysis of scales

\begin{tabular}{lcc}
\hline \multicolumn{1}{c}{ Construct } & No. of Items & Cronbach's Alpha \\
\hline Perceived Usefulness & 7 & 0.74 \\
Perceived Ease of Use & 7 & 0.68 \\
Perceived Price & 6 & 0.66 \\
Perceived Convenience & 7 & 0.59 \\
Perceived Trust & 7 & 0.60 \\
Intention to Use & 7 & 0.57 \\
\hline
\end{tabular}

\section{Part Three: Hypotheses Testing}

This part indicates the hypotheses testing and the result. Table 4 show the five full statement of the research hypotheses. H1, $\mathrm{H} 2, \mathrm{H} 3, \mathrm{H} 4$ and $\mathrm{H} 5$ were tested using the correlation analysis and standard multiple regression analysis.

Table 4: Research Hypotheses

\begin{tabular}{ll}
\hline H1 & $\begin{array}{l}\text { There is significant relationship between perceived usefulness and intention to use } \\
\text { Shopee among consumer in East Coast Malaysia. }\end{array}$ \\
\hline H2 & $\begin{array}{l}\text { There is significant relationship between perceived ease of use and intention to use } \\
\text { Shopee among consumer in East Coast Malaysia. }\end{array}$ \\
\hline H3 & $\begin{array}{l}\text { There is significant relationship between perceived price and intention to use Shopee } \\
\text { among consumer in East Coast Malaysia. }\end{array}$ \\
\hline H4 & $\begin{array}{l}\text { There is significant relationship between perceived convenience and intention to use } \\
\text { Shopee among consumer in East Coast Malaysia. }\end{array}$ \\
\hline H5 & $\begin{array}{l}\text { There is significant relationship between perceived trust and intention to use Shopee } \\
\text { among consumer in East Coast Malaysia. }\end{array}$ \\
\hline
\end{tabular}

\section{Part 4: Relationship between Variables}

The relationship between variables consists of five hypotheses: H1, H2, H3, H4 and H5 were tested by using Pearson productmoment correlation (r). The two-tail tests of significance were executed as stated in the research hypotheses. Table 5 shows the result of Pearson's Correlation Matrix. The variable of perceived usefulness, perceived ease of use, perceived price, perceived convenience, and perceived trust shows that significant. Perceived convenience shows the highest association with intention to use. All coefficients of correlation between the variables are highly significant. The analysis of the relationship between variable provides support for $\mathrm{H} 1, \mathrm{H} 2, \mathrm{H} 3$, $\mathrm{H} 4$ and $\mathrm{H} 5$. 
Table 5: Pearson's correlation matrix (in $\mathrm{N}=208$, two-tailed in all cases)

\begin{tabular}{|c|c|c|c|c|c|c|c|}
\hline & & $\begin{array}{l}\text { Perceived } \\
\text { Usefulness }\end{array}$ & $\begin{array}{r}\text { Perceived } \\
\text { Ease of Use }\end{array}$ & $\begin{array}{l}\text { Perceived } \\
\text { Price }\end{array}$ & $\begin{array}{c}\text { Perceived } \\
\text { Convenience }\end{array}$ & $\begin{array}{c}\text { Perceived } \\
\text { Trust }\end{array}$ & Intention \\
\hline \multirow{2}{*}{$\begin{array}{l}\text { Perceived } \\
\text { Usefulness }\end{array}$} & $\mathrm{r}$ & - & $.340 * *$ & $.226 * *$ & $.407 * *$ & $.288^{* *}$ & $.279 * *$ \\
\hline & Sig. & & .000 & .001 & .000 & .000 & .000 \\
\hline \multirow{2}{*}{$\begin{array}{l}\text { Perceived Ease } \\
\text { of Use }\end{array}$} & $r$ & & - & $.377 * *$ & $.470 * *$ & $.416^{* *}$ & $.382 * *$ \\
\hline & Sig. & & & .000 & .000 & .000 & .000 \\
\hline \multirow{2}{*}{$\begin{array}{l}\text { Perceived } \\
\text { Price }\end{array}$} & $\mathrm{r}$ & & & - & $.502 * *$ & $.318^{* *}$ & $.371^{* *}$ \\
\hline & Sig. & & & & .000 & .000 & .000 \\
\hline \multirow{2}{*}{$\begin{array}{l}\text { Perceived } \\
\text { Convenience }\end{array}$} & $\mathrm{r}$ & & & & - & $.373 * *$ & $.508^{* *}$ \\
\hline & Sig. & & & & & .000 & .000 \\
\hline \multirow{2}{*}{$\begin{array}{l}\text { Perceived } \\
\text { Trust }\end{array}$} & $\mathrm{r}$ & & & & & - & $.409 * *$ \\
\hline & Sig. & & & & & & .000 \\
\hline \multirow[t]{2}{*}{ Intention } & $\mathrm{r}$ & & & & & & - \\
\hline & Sig. & & & & & & \\
\hline
\end{tabular}

**Correlation is significant at the 0.01 level (2- tailed)

Part 5: Degree of Relationship between Variables

In this research, standard multiple regressions were used to explore the degree of the relationship between perceived ease of use, perceived price, perceived trust, and intention to use Shopee platform. The result of multiple regression analysis was interpreted and reported by standard path coefficients and Adjusted R Square which shows the dependent variable is caused by effect of independent variables (Lund Research Ltd, 2018). The aims of these analyses are to determine how well the independent variables collectively explain and predict the current research framework of this study (Rosufila, Z et al., 2018). The findings from Table 6 show that no tolerance value falls below 0.1 and no VIF (Variance Inflation Factor) exceeds 10. Table 6 shows the results of standard multiple regression analysis.
Perceived usefulness, perceived ease of use, perceived price, perceived convenience, and perceived trust collectively explains $32 \%$ of the variance in intention to use Shopee platform. This percentages are highly significant. Perceived convenience has the largest and strongest beta value. This mean that perceived convenience and perceived trust makes the strongest unique contribution to explain the dependent variable. Perceived usefulness, perceived ease of use and perceived price does not make a significant unique contribution to the prediction of the dependent variable. This may be due to overlap with other independent variables in the model (Rosufila, Z et al., 2018). In conclusion, the standard multiple regression analysis provides support for the result of $\mathrm{H} 1, \mathrm{H} 2$, $\mathrm{H} 3, \mathrm{H} 4$ and $\mathrm{H} 5$ from the previous analysis. 
Table 6: Standard multiple regression analysis

\begin{tabular}{lccccccc}
\hline \multicolumn{1}{c}{ Model } & $\mathbf{F ~ 5 , 2 0 8}$ & Sig. & Adjusted $\mathbf{R}^{2}$ & $\beta$ & Sig. & T & VIF \\
\hline Intention & 20.01 & 0.000 & 0.32 & & & & \\
\hline $\begin{array}{l}\text { Perceived } \\
\text { Usefulness }\end{array}$ & & & $\mathbf{0 . 0 3}$ & $\mathbf{0 . 6 0}$ & 0.52 & 1.26 \\
\hline $\begin{array}{l}\text { Perceived } \\
\text { Ease of Use }\end{array}$ & & & $\mathbf{0 . 0 9}$ & $\mathbf{0 . 1 8}$ & 1.35 & 1.47 \\
\hline $\begin{array}{l}\text { Perceived } \\
\text { Price }\end{array}$ & & $\mathbf{0 . 1 0}$ & $\mathbf{0 . 1 5}$ & 1.46 & 1.40 \\
\hline $\begin{array}{l}\text { Perceived } \\
\text { Convenience }\end{array}$ & & 0.32 & 0.00 & 4.33 & 1.68 \\
\hline $\begin{array}{l}\text { Perceived } \\
\text { Trust }\end{array}$ & & & 0.21 & 0.002 & 3.17 & 1.31 \\
\hline
\end{tabular}

\section{Conclusion}

The present research has demonstrated that the findings derived able to explain factors that influenced consumer to choose Shopee as their online shopping platform in the East Coast of Malaysia. The findings from correlation analysis show that perceived usefulness, perceived ease of use, perceived price, perceived convenience, and perceived trust have a positive significant relationship with intention to use. The study highlights that the ratio of the gender was 2:1 which showed that most of the respondents were Chinese female aged between 18 to 25 use Shopee for online shopping in East Coast of Malaysia. It is also found that most of the female respondents are students with a bachelor's degree and annual income below RM10000 that wishes to spend below RM100 to purchase clothes and accessories items in Shopee. It has been supported by Sawitri and Giantari (2020) that Shopee users come from all genders and most users are ranged from teenagers to adults. The study also reveals that the perceived convenience has the most influencing factor on online purchase. The second most influencing factor is the perceived trust.

This study has indicated that perceived convenience has given the strongest influence in consumer intention to use Shopee. It may indicate that Shopee platform provide complete information and easiness in accessing Shopee to increase more consumer intention to use it. Findings from previous research of the consumers' perception on online shopping convenience demonstrated online shopping platform allows consumer to shop comfortably and with convenience without any stress or interference from other people (Shanthi \& Desti, 2015). The major reason that most of the consumer prefer using online shopping platform to purchase due to convenience and save a lot of time and effort during the transaction proses. Thus, perhaps it can be said that the majority of consumer consider that perceived convenience is the most important consideration as it is easier to navigate and accessible. Hence, it is suggested for practitioners such as Shopee to focus more on consumer online shopping experience via mobile with functional Shopee website across as many devices as possible. This is to avoid any poor website browsing which can easily lead to consumer frustration of using Shopee. In addition, Shopee website loading time should also be faster to ensure consumer will not grow impatient while browsing through Shopee website.

Perceived trust in using Shopee also has an important effect on the purchase intentions for consumers in East Coast of 
Malaysia. It can be said that the higher level of consumer perceived trust towards Shopee, the more consumer purchase intention in Shopee platform. Findings from previous study on the effect of trust and perceived value towards purchase intention to use Shopee also show that the variable trust have the most significant influence on consumer's intention to use Shopee (Rafsandjani, 2018). Hence, perhaps it can be said that consumer consider first and foremost, the variable perceived trust driven from purchase intention to use Shopee. It is recommended for practitioners especially Shopee to keep building trust in the minds of consumer by increasing and protecting consumer privacy as well as other basic consumer rights. It has also been suggested by Sawitri and Giantari (2020) that it is better for Shopee to create a strong customer connection by displaying interesting advertisement and giving surprises or gifts in order to maintain consumer loyalty from switching to other online shopping platform.

There are some limitations which can be improved for future study. The sample of this study is concentrated on consumer in East Coast of Malaysia. Hence, the present study should be replicated to consumer in other states in Malaysia as well. The survey data in this study need to cover more general population instead of students and respondents aged 18-30 ( $\mathrm{Li}$ et al., 2007). Thus, in the next study, researcher should implement qualitative and quantitative method to adequately collect data from general population in all range of aged in Malaysia to deeply evaluate respondent perception and intention to use Shopee. Furthermore, this study can also be extended by studying on the Theory of Planned Behavior (TPB).

\section{Acknowledgements}

The present research was made possible by the guidance, advice and support from supervisor, parents, and friends.

\section{References}

Abu Hasan, Z. (2011). Interpreting green consumer behaviour: an exploratory examination of Cardiff consumers (Doctoral dissertation, Cardiff University).

Ahmed, Z., Su, L., Rafique, K., Khan, S. Z., \& Jamil, S. (2017). A study on the factors affecting consumer buying behavior towards online shopping in Pakistan. Journal of Asian Business Strategy, 7(2), 44.

Aineah, B. N. (2016). Factors Influencing Online Purchasing Intention among College Students in Nairobi City (Doctoral dissertation, United States International University-Africa).

Alias, A. (2018). Malaysia's Internet penetration is now 85.7 per cent. [Online]. Retrieved from https://www. nst.com.my/business/2018/03/346978/ malaysias-internet-penetration-now857-cent.

Burns, A. C., \& Bush, R. F. (2014). Marketing Research. England: Pearson.

Chiang, K. P., \& Dholakia, R. R. (2003). Factors driving consumer intention to shop online: an empirical investigation. Journal of Consumer psychology, 13(1), 177-183.

ComplaintsBoard.com (2019). Shopee Complaints \& Reviews [Online]. Retrieved from https:// www.complain ts board.com/ shopee-b127739/page/2.

Delafrooz, N., Paim, L. H., Haron, S. A., Sidin, S. M., \& Khatibi, A. (2009). Factors affecting students' attitude toward online shopping. African Journal of Business Management, 3(5), 200-209.

Fenech, T. (2000). Attitude and Security do count for shopping on the World Wide Web. In Proceedings of ANZMAC 2000 Conference: Visionary Marketing 
for the 21st Century: Facing the Challenge.

Gupta, P. (2015). Comparative study of online and offline shopping: A case study of Rourkela in Odisha (Master dissertation).

iPrice (2018). The Map of E-commerce in Malaysia [Online]. Retrieved from https://iprice.my/insights/ mapofecommerce/en/.

Kim, A. J., \& Ko, E. (2012). Do social media marketing activities enhance customer equity? An empirical study of luxury fashion brand. Journal of Business Research, 65(10), 1480-1486

Kim, J. (2004). Understanding consumers' online shopping and purchasing behaviors (Doctoral dissertation, Oklahoma State University).

Li, N., \& Zhang, P. (2002). Consumer online shopping attitudes and behavior: An assessment of research. AMCIS 2002 Proceedings, 74.

Liat, C. B., \& Wuan, Y. S. (2014). Factors influencing consumers' online purchase intention: A study among university students in Malaysia. International Journal of Liberal Arts and Social Sciences, 2(8), 121-133.

Liew, Y. S. (2015). Factors Influencing Consumers Purchase Intention towards Online Group Buying in Malaysia (Master dissertation, UTAR).

Lim, B. (2017). Insights: The Shopee Business Model \& Revenue Model. [Online]. Retrieved from https://www. nexea.co/insights-shopee-businessmodel-revenue/.

Lin, H. F. (2007). Predicting consumer intentions to shop online: An empirical test of competing theories. Electronic Commerce Research and Applications, 6(4), 433-442.
Lund Research Ltd. (2018). Multiple Regression Analysis using SPSS Statistics. [Online]. Retrieved from https://statistics.laerd.com/spsstutorials/multiple-regression-usingspss-statistics.php.

Nee, E.A. (2017). E-commerce Marketplace Shopee to Monetise Platform, Starting With Paid Ads. [Online]. Retrieved from www.thesundaily. my/news/2017/08/18/e-commercemarketplace-shopee-monetiseplatform-starting-paid-ads.

Pardede, C. R., Lapian, S. J., \& Pandowo, M. (2018). The influence of perceived value and trust on repurchase intention in Shopee online shopping. Jurnal EMBA: Jurnal Riset Ekonomi, Manajemen, Bisnis dan Akuntansi, 6(1).

Rafsandjani, R. F. (2018). Analyzing the effect of trust and perceived value on purchase intention (Case Study of Shopee). Management and Economics Journal (MEC-J), 71-84.

Rana, S. S., Osman, A., \& Othman, Y. H. (2015). Factors affecting purchase intention of customers to shop at hypermarkets. Mediterranean Journal of Social Sciences, 6(3), 429.

Rosufila, Z., Fadzanaquieah, F., Ahmad, N. M., \& Hasan, N. A. (2018). Get them all: influence of pokémon go among student. Journal of Business and Social Development, 6 (1), March 2018: 157165.

Sam, M., Fazli, M., \& Tahir, M. N. H. (2009). Website quality and consumer online purchase intention of air ticket.

Sarkar, A. (2011). Impact of utilitarian and hedonic shopping values on individual's perceived benefits and risks in online shopping. International management review, 7(1), 58-65. 
Sawitri, N. L. P. W., \& Giantari, I. G. A. Tan, S. H., Chan, I. Y. W., Lee, H. K. (2020). The role of trust mediates the effect of perceived ease of use and perceived usefulness on online repurchase intention. American Journal of Humanities and Social Sciences Research, 4(1), 374-381.

Shanthi, R., \& Desti, K. (2015). Consumers' perception on online shopping. Journal of Marketing and Consumer Research, 13, 14-21.

Shopee (2019). Shopee [Online]. Retrieved from https:// shopee.commy/?gclid=EAIa I QobChMI9fq4wffZ5QIVgyQrCh1_ TAhsEAAYASAAEgIoIfD_BwE.

Surendran, P. (2012). Technology acceptance model: A survey of literature. International Journal of L., Leong, H. Y., \& Teoh, S. K. (2011). Relationship between perceived benefits and undergraduates, online shopping decisions in Malaysia (Degree dissertation, UTAR).

The Sun Daily (2018). Lazada, Shopee, 11Street Top E-commerce Ranking [Online]. Retrieved from https://www. thesundaily.my/archive/lazada-shopee11 street-top-e-commerce-rankingXUARCH571776.

Tingchi Liu, M., Brock, J. L., Cheng Shi, G., Chu, R., \& Tseng, T. H. (2013). Perceived benefits, perceived risk, and trust: Influences on consumers' group buying behaviour. Asia Pacific Journal of Marketing and Logistics, 25(2), 225248.

Business and Social Research, 2(4), 175-178. 